\title{
Occurrence of extended-spectrum beta-lactamases in human and bovine isolates of Escherichia coli from Oyo state, Nigeria
}

\author{
Christiana Inwezerua ${ }^{1}$, Nuno Mendonça ${ }^{2}$, Vera Calhau², Sara Domingues², Olufemi Ezekiel Adeleke ${ }^{1}$, \\ Gabriela Jorge Da Silva² \\ ${ }^{1}$ Deparment of Pharmaceutical Microbiology, University of Ibadan, Oyo state, Nigeria \\ ${ }^{2}$ Center of Pharmaceutical Studies, Faculty of Pharmacy, University of Coimbra, Coimbra, Portugal
}

*Present affiliation: Faculty of Pharmacy and Center of Neurosciences and Cell Biology, University of Coimbra, Portugal

\begin{abstract}
Introduction: The main objective of the study was the molecular characterization of extended spectrum $\beta$-lactamases (ESBL) in Escherichia coli isolates collected from human and bovine samples in Oyo state, Nigeria.

Methodology: Between August 2010-2011, 114 E. coli isolates were collected from hospitals $(\mathrm{n}=57)$ and bovine $(\mathrm{n}=57)$. PCR and sequencing were used for identification of ESBLs, upstream sequences, plasmid-mediated quinolone resistance (PMQR) genes and class 1 integrons. Plasmid incompatibility groups were identified among ESBL-positive isolates by PCR. Genetic relatdness was assessed by repPCR and MLST. Transfer of ESBL determinants to the recipient strain E. coli J53 was performed by broth mating assays.

Results: CTX-M15 was the unique ESBL found in eight human isolates. Six CTX-M-15 producers also carry the $a a c\left(6^{\prime}\right)-l b-c r$ gene and/or $q n r B$ gene, and class 1 integrons. FIA, FIB, H11, H12, F, Y and K were the plasmid replicon types found. CTX-M-15 and PMQR determinants were transferred by conjugation in two E. coli assigned by MLST to ST131 and ST2695, a new allele.

Conclusions: The study highlights the dissemination hability of CTX-M-15 associated with PMQR, and the presence of class 1 integrons, able to capture additional genes, justifying the urgent need of antimicrobial resistance surveillance in Nigeria.
\end{abstract}

Key words: Escherichia coli; extended-spectrum beta-lactamases; plasmid-mediated quinolone resistance; genetic mobile elements

J Infect Dev Ctries 2014; 8(6):774-779. doi:10.3855/jidc.3430

(Received 18 February 2013 - Accepted 09 May 2013)

Copyright $(\mathbb{C} 2014$ Inwezerua et al. This is an open-access article distributed under the Creative Commons Attribution License, which permits unrestricted use, distribution, and reproduction in any medium, provided the original work is properly cited.

\section{Introduction}

Extended-spectrum $\beta$-lactamases (ESBLs) are plasmid borne, and are harbored by Gram-negative bacteria. They can be divided into three major groups: TEM, SHV, and CTX-M types [1]. ESBL-producing strains can increase morbidity and mortality rates, in part as a result of associated resistance to other antibiotic families, which limits therapeutic options and raises healthcare costs [2]. Plasmid-mediated quinolone resistance genes (PMQRs) have been reported to be associated with ESBLs (and other $\beta$ lactamases) [3]. Many reports have described and characterized ESBLs in Klebsiella spp. and Escherichia coli, including reports from African countries [4,5]. However, few reports on the prevalence of ESBL and PMQR determinants in both human and bovine isolates in Nigeria have been documented. A recent study reported high rates of resistance to quinolones in association with $\beta$-lactams among $E$. coli isolates from healthy animals in Nigeria
[6]. Thus, the objectives of this study were to determine the prevalence of ESBL in E. coli clinical isolates from human and bovine origins collected in Oyo state, Nigeria, to perform their molecular characterizations, and to assess their potential dissemination.

\section{Methodology \\ Bacterial isolates}

Between August 2010 and August 2011, 57 E. coli isolates were collected from different inpatients from four hospitals located in Oyo state, Nigeria: two tertiary care hospitals (University College Hospital Ibadan and Bowen Teaching Hospital Ogbomoso), and two secondary hospitals (Oluyoro Catholic Hospital Ibadan and General Hospital Adeoyo Ibadan). During the same period, $57 \mathrm{E}$. coli isolates were also isolated from fecal samples of different healthy bovine animals from diverse farms at slaughter in Oyo state, Nigeria. 
Farms from three different locations (Ibadan, Ogbomoso, and Iseyin) were included in the study.

\section{Susceptibility testing and phenotypic ESBL detection}

Susceptibility testing for 12 antibiotics was performed using the Kirby-Bauer method. Results were interpreted using Clinical Laboratory and Standards Institute criteria [7]. The double disk synergy test was used to screen the production of ESBLs in all isolates [8].

Identification of ESBL genes and upstream sequences, $P M Q R$ genes, and class 1 integrons

PCR was used to screen for $b l a_{\mathrm{TEM}}, b l a_{\mathrm{CTX}-\mathrm{M}}$, and $b l a_{\mathrm{SHV}}$ types of $\beta$-lactamases using specific primers [9] in presumptive ESBL producers. $E$ coli 39FFC (bla $\left.a_{\mathrm{TEM}}\right)$, E. coli 144FFC (bla CTХ-M $)$, and Klebsiella pneumoniae $339 \mathrm{FFC}\left(\right.$ bla $\left._{\mathrm{SHV}}\right)$ were used as positive controls. PCR products were purified with Exosap IT (Affymetrix, Santa Clara, USA), and sequenced in both strands (Macrogen, Seoul, Korea). Nucleotide sequences were analyzed with BioEdit software, and database searches were performed using the National Center for Biotechnology Information website (www.ncbi.nlm.nih.gov).

All isolates were screened by multiplex PCR for the most common qnr genes: qnrA, qnrB, and $q n r S$ [10]. Two simplex PCRs were carried out to detect $a a c\left(6^{\prime}\right)-l b$ and qepA genes [12-13]. Human isolates positive for the $a a c\left(6^{\prime}\right)-l b$ gene were further analyzed by digestion with a BtsCI enzyme (New England Biolabs Ipswich, USA) to identify $a a c\left(6^{\prime}\right)-l b-c r$, which lacks the BtsCI restriction site present in the wild type gene [11]. ISEcp, Is26, and Is 903 elements were investigated in the ESBL-positive isolates [9].

Integrase gene, intIl, was screened by PCR in ESBL-positive and Qnr-positive isolates [12]. Isolates positive for intIl were subjected to amplification with 5 '-CS and 3'-CS primers [13] to amplify the variable region of class 1 integrons. PCR products were purified and sequenced as previously described.

\section{Plasmid replicon typing}

Plasmid incompatibility groups were identified among positive ESBL isolates. The PCR-based Inc/rep typing method consists of five multiplex-PCRs recognizing three different replicon types and three simplex PCRs for K, F, and B/O replicon types [14].

\section{Conjugation experiments}

The transfer of ESBL determinants to the recipient strain E. coli J53 (sodium azide resistant) was performed by broth mating assays, at a bacterial cell ratio of 1:10. Overnight cultures were centrifuged, the sediment suspended in $50 \mu \mathrm{L}$ of PBS buffer, and 20 $\mu \mathrm{L}$ were plated in duplicates of Luria-Bertani agar containing sodium azide $(100 \mathrm{mg} / \mathrm{L})$ and cefotaxime $(1 \mathrm{mg} / \mathrm{L})$. The antibiotic susceptibility profile was determined for transconjugants by the disk diffusion method. PCR amplification of the ESBL determinants and plasmid replicon types was also performed to confirm the transfer of resistance determinants and to identify the plasmid replicon type involved in the transfer of resistance, using the methodology described.

\section{Genetic relatedness and sequence typing by MLST}

The rep-PCR genomic fingerprinting method was performed on the ESBL producers to assess their genetic relatedness [15]. Multilocus sequence typing (MLST) analysis was performed [16] on the two ESBL-positive strains that were successful on conjugation assays.

\section{Results}

Origin of bacterial isolates, antibiotic susceptibility, and phenotypic detection of ESBLS

Of the isolates from human clinical samples, 34 were from urine, 10 were from high vaginal swabs, 9 were from stool, 3 were from suptum, and 1 was from an endocervical swab. The majority of the human samples $(54 \%)$ were isolated from the University College Hospital (UCH), the first teaching hospital in Nigeria. Seventy-four percent of the bovine samples (n $=42$ ) were obtained from farms in Ibadan, which is the capital city of Oyo state and the third-largest metropolitan area in Nigeria.

Table 1 shows the susceptibility profiles obtained for the isolates. As shown, the bovine isolates were more susceptible to the antimicrobials tested than were the human isolates. ESBLs were only detected in the human E. coli isolates. ESBL-positive strains were also resistant to gentamicin $(87.5 \%)$, nalidixic acid $(62.5 \%)$, and ciprofloxacin $(50 \%)$, but susceptible to cefoxitin and imipenem (100\%). The ESBL-producing isolates were predominantly isolated from urine samples, followed by high vaginal swabs.

\section{Characterization of ESBL and PMQR}

Table 2 summarizes the molecular characterization of ESBL producers and a bovine isolate. CTX-M-15 enzyme was identified in eight human $E$. coli isolates, confirming the resistance phenotype. All isolates also carried the non-ESBL bla $a_{\mathrm{TEM}-1}$. Two and six E. coli 
$b l a_{\mathrm{CTX}-\mathrm{M}-15}$ producers showed the $q n r B$ and $a a c\left(6^{\prime}\right)-l b$ $c r$-variant genes, respectively. Two isolates carried both the $q n r B$ and $a a c$ (6)-lb-cr genes. A single bovine strain carried the $q n r S$ gene. ESBLs and other PMQRs were not found in the bovine isolates.

An ISEcpl element was detected upstream of the $b l a_{\text {CTX-M-15 }}$ gene. The IS26 element was located in three of the ESBL producers, and one isolate had both the IS26 and IS903 elements.

Rep-PCR identified three DNA fingerprint patterns among the $b l a_{\mathrm{CTX}-\mathrm{M}-15}$ producers. They were from two hospitals in Oyo state; UCH had the highest number of isolates $(n=7)$. Most of the isolates shared a common fingerprinting pattern (data not shown).

\section{Plasmid identification}

Plasmids carrying the CTX-M-15 $\beta$-lactamase and the PMQRs determinants were assigned to the FIA, FIB, HI2, F, and $\mathrm{K}$ replicon types (Table 2). In the bovine strain, plasmids were assigned to the HII, FIB, and $\mathrm{Y}$ incompatibility groups.

\section{Conjugation assays}

Transfer by conjugation of the ESBL and PMQR phenotypes to E. coli J53 was successful for two out of the eight $b l a_{\text {CTX-M-5-positive strains. The }}$ transconjugants showed resistance profiles identical to the donors. The $b l a_{\mathrm{TEM}-1}, b l a_{\text {СTX-M-15, }}$ aac(6')-lb-crvariant, and $q n r B$ genes were confirmed to be present in transconjugants. The transferred plasmids were assigned to the FIB and HI2 replicon types (Table 2). $E$. coli with conjugative plasmids belonged to different sequence types; H15, carrying aac(6')-lb-cr, bla $a_{\mathrm{TEM}-1}$, and $b l a_{\text {СтХ-M-15, was identified as ST131, while E. coli }}$ $\mathrm{H} 1$, harboring $q n r B$, aac(6')-lb-cr-variant, bla TEM-1$_{1}$, and $b l a_{\mathrm{CTX}-\mathrm{M}-15}$, was assigned to ST2695, a new allele.

\section{Characterization of class 1 integrons}

The intIl gene was present in the qnrS-borne bovine strain (no gene cassettes inserted in the variable region) and in $87.5 \%$ of the human ESBL-positive isolates. Two different gene cassette arrays were identified in six ESBL-positive isolates: aadA1, encoding resistance to streptomycin and spectinomycin, and dfrA17-aadA5, encoding resistance to streptomycin/spectinomycin and trimethoprim (Table 2).

\section{Discussion}

ESBLs, especially CTX-M-15 $\beta$-lactamase, usually located in conjugative plasmids, are disseminated worldwide. This study confirmed the presence of CTX-M-15 in human clinical isolates in Nigeria, though at a moderate prevalence. A strong association between ESBL production and quinolone resistance has been reported in Enterobacteriaceae [2]. In this study, the resistance to nalidixic acid and ciprofloxacin shown by the CTX-M-15 producers could be linked partially to the simultaneous carriage of PMQRs. The $a a c\left(6^{\prime}\right)-l b-c r$-variant was shown to be prevalent; $q n r B$ was found in two isolates. Five different plasmid replicon types (H12, FIA, FIB, F, and $\mathrm{K}$ ) were identified, but only FIB, H12, and $\mathrm{K}$ were shown to conjugate. Both CTX-M-15 and TEM-1 determinants, as well as the $q n r B$ and $a a c\left(6^{\prime}\right)-l b-c r-$ variant, could be transferred (Table 2), demonstrating the potential of co-dissemination by horizontal gene transfer of resistance to $\beta$-lactams and quinolones. Recently, a study reported high rates of resistance to $\beta$ lactams and quinolones among Gram-negative isolates from different hospitals in Nigeria [17], which may support our findings at a molecular level..

Table 1. Antibiotic susceptibility pattern of the human and bovine E. coli isolates

\begin{tabular}{|c|c|c|c|c|c|c|}
\hline \multirow[b]{2}{*}{ Antibiotics } & \multicolumn{3}{|c|}{ Human (\%) } & \multicolumn{3}{|c|}{ Bovine (\%) } \\
\hline & $\mathbf{R}$ & I & $\mathbf{S}$ & $\mathbf{R}$ & $\mathbf{I}$ & $\mathbf{S}$ \\
\hline Amoxicillin & 88 & 0 & 12 & 18 & 5 & 77 \\
\hline Amoxicillin plus clavulanic acid & 30 & 47 & 23 & 0 & 0 & 100 \\
\hline Ceftazidime & 9 & 4 & 88 & 0 & 2 & 98 \\
\hline Cefotaxime & 14 & 5 & 81 & 0 & 0 & 100 \\
\hline Aztreonam & 5 & 9 & 81 & 0 & 0 & 100 \\
\hline Cefepime & 0 & 4 & 97 & 0 & 0 & 100 \\
\hline Imipenem & 0 & 2 & 98 & 0 & 0 & 100 \\
\hline Cefoxitine & 0 & 0 & 100 & 0 & 0 & 100 \\
\hline Nalidixic acid & 47 & 4 & 49 & 4 & 0 & 97 \\
\hline Ciprofloxacin & 40 & 0 & 60 & 0 & 0 & 100 \\
\hline Trimethoprim & 83 & 0 & 18 & 25 & 0 & 75 \\
\hline Gentamicin & 46 & 0 & 54 & 0 & 0 & 100 \\
\hline
\end{tabular}

R: resistance, I: intermediate, S: susceptible 
Table 2. Origin, antimicrobial resistance pattern, and genetic characteristics of human and bovine $E$. coli isolates

\begin{tabular}{|c|c|c|c|c|c|c|c|c|c|c|}
\hline Strain & $\begin{array}{l}\text { Hospital/farm } \\
\text { location }^{\mathrm{a}}\end{array}$ & Specimen $^{\mathrm{b}}$ & $\begin{array}{l}\text { Antimicrobial } \\
\text { resistance pattern }\end{array}$ & $\begin{array}{l}\text { PMQR } \\
\text { gene }\end{array}$ & $\begin{array}{l}\beta \text {-lactamase } \\
\text { gene }\end{array}$ & $\begin{array}{l}\text { Transferred } \\
\text { genes }^{\mathrm{d}}\end{array}$ & $\begin{array}{l}\text { Plasmid } \\
\text { replicon }\end{array}$ & $\begin{array}{c}\text { Is } \\
\text { elements }\end{array}$ & $\begin{array}{c}\text { Gene } \\
\text { cassette(s) } \\
\text { on integrons }\end{array}$ & $\mathbf{S T}^{\mathrm{e}}$ \\
\hline BV36 & Ibadan & Feces & W/AML & QnrS & - & - & HII, Y, FIB & - & - & - \\
\hline $\mathrm{H} 1$ & $\mathrm{UCH}$ & Urine & $\mathrm{CZ} / \mathrm{CT} / \mathrm{AT} / \mathrm{W} / \mathrm{CN} / \mathrm{AML}$ & $Q n r \mathrm{~B}, a a c\left(6^{\prime}\right)-l b-c r$ & $\begin{array}{l}\text { bla }_{\mathrm{TEM}-1} \\
\text { bla }_{\mathrm{CTX}-\mathrm{M} 15}\end{array}$ & $\begin{array}{c}\text { QnrB, aac (6')-lb-cr, } \\
\text { bla }_{T E M}, \text { bla }_{C T X-M 15}\end{array}$ & FIB, H12, K & IsEcpl & aadAl & 2695 \\
\hline H6 & $\mathrm{UCH}$ & Urine & $\mathrm{CZ} / \mathrm{CT} / \mathrm{NA} / \mathrm{W} / \mathrm{AML}$ & - & $\begin{array}{l}\text { bla }_{\mathrm{TEM}-1} \\
\text { bla }_{C T X-M 15}\end{array}$ & - & FIB & $\begin{array}{l}\text { IsEcp } 1 \\
\text { IS } 26\end{array}$ & aadA5,dfrA17 & - \\
\hline H12 & $\mathrm{UCH}$ & HVS & $\begin{array}{c}\mathrm{CZ} / \mathrm{CT} / \mathrm{AT} / \mathrm{CIP} / \mathrm{NA} / \mathrm{W} / \mathrm{CN} / \\
\mathrm{AML}\end{array}$ & $a a c\left(6^{\prime}\right)-l b-c r$ & $\begin{array}{l}\text { bla }_{\mathrm{TEM}^{-1}} \\
\text { bla }_{\mathrm{CTX-M} 15}\end{array}$ & - & FIA, FIB & IsEcpl & $\begin{array}{l}\text { aadA5, } \\
\text { dfrA17 }\end{array}$ & - \\
\hline H13 & $\mathrm{UCH}$ & HVS & $\mathrm{CZ} / \mathrm{CT} / \mathrm{CIP} / \mathrm{NA} / \mathrm{W} / \mathrm{CN} / \mathrm{AML}$ & - & $\begin{array}{c}\text { bla }_{\mathrm{TEM}-1} \\
\text { bla }_{\text {CTX-M } 15}\end{array}$ & - & FIA, FIB & $\begin{array}{l}\text { IsEcp1, } \\
\text { IS } 26\end{array}$ & - & - \\
\hline H15 & GHA & HVS & $\begin{array}{c}\mathrm{CZ} / \mathrm{CT} / \mathrm{AMC} / \mathrm{AT} / \mathrm{CIP} / \mathrm{NA} / \mathrm{W} / \\
\mathrm{CN} / \mathrm{AML}\end{array}$ & $a a c\left(6^{\prime}\right)-l b-c r$ & $\begin{array}{l}\text { bla }_{\text {TEM-1 }} \\
\text { bla }_{\text {CTX-M } 15}\end{array}$ & $\begin{array}{c}a a c\left(6^{\prime}\right)-l b-c r, b l a_{T E M}, \\
\text { bla }_{C T X-M 15}\end{array}$ & FIB & IsEcpl & - & 131 \\
\hline $\mathrm{H} 22$ & $\mathrm{UCH}$ & Urine & $\begin{array}{c}\mathrm{CZ} / \mathrm{CT} / \mathrm{AMC} / \mathrm{CIP} / \mathrm{NA} / \mathrm{W} / \mathrm{CN} / \\
\mathrm{AML}\end{array}$ & $a a c\left(6^{\prime}\right)-l b-c r$ & $\begin{array}{l}\text { bla }_{\mathrm{TEM}-1} \\
b^{\prime} a_{\mathrm{CTX}-\mathrm{M} 15}\end{array}$ & - & FIA,FIB & IsEcpl & $\begin{array}{l}\text { aadA5, } \\
\text { dfrA17 }\end{array}$ & - \\
\hline H45 & $\mathrm{UCH}$ & Urine & $\mathrm{CT} / \mathrm{W} / \mathrm{CN} / \mathrm{AML}$ & $a a c\left(6^{\prime}\right)-l b-c r$ & $\begin{array}{l}\text { bla }_{\mathrm{TEM}-1} \\
\text { bla }_{\mathrm{CTX}-\mathrm{M} 15}\end{array}$ & - & H12, K, FREPB & $\begin{array}{l}\text { IsEcpl, } \\
\text { IS26 }\end{array}$ & aadAl & - \\
\hline $\mathrm{H} 47$ & $\mathrm{UCH}$ & Urine & $\mathrm{CT} / \mathrm{AMC} / \mathrm{W} / \mathrm{CN} / \mathrm{AML}$ & $Q n r \mathrm{~B}, a a c\left(6^{\prime}\right)-l b-c r$ & $\begin{array}{l}\text { bla }_{\mathrm{TEM}-1} \\
\text { bla }_{\mathrm{CTX}-\mathrm{M} 15}\end{array}$ & - & H12, FREPB & $\begin{array}{c}\text { IsEcp1, } \\
\text { IS } 26, \\
\text { Is } 903\end{array}$ & aadAl & - \\
\hline
\end{tabular}

${ }^{a}$ UCH: University College Hospital, Ibadan; GHA: General Hospital Adeoyo, Ibadan

HVS: high vaginal swabs

${ }^{\circ} \mathrm{CZ}$ : ceftazidime; CT: cefotaxime; AT: aztreonam; W: trimethoprim; CN: gentamicin; AML: amoxicillin; NA: nalidixic acid; CIP: ciprofloxacin; AMC: amoxicillin plus clavulanic acid

d - No transferred gene. Conjugation not successful.

e, Sequence type 
Nevertheless, only two E. coli were able to conjugate; these belonged to distinct sequence types, as determined by MLST. ST131 was identified as carrying $b l a_{\text {СTX-M-15 }}$ and $a a c\left(6^{\prime}\right)-l b-c r$. The first report recently made in West Africa of E. coli ST131 harboring $b l a_{\mathrm{CTX}-\mathrm{M}-15}$ and $a a c\left(6^{\prime}\right)-l b-c r$, found predominantly among hospital isolates, was from Lagos, Nigeria [18]. Our results support the dissemination of this strain in the country, since they were collected in a different state. The other $b l a_{\text {CTX-M- }}$ ${ }_{15} E$. coli, harboring the $q n r \mathrm{~B}$ and $a a c\left(6^{\prime}\right)-l b-c r$ genes, was assigned to ST2695, a new allele, not previously reported to be associated with CTX-M-15.

The IncF plasmidic family was the most common found in this study; it includes the F1A and F1B groups frequently reported to be associated with CTX$\mathrm{M}$ and $a a c\left(6^{\prime}\right)-\mathrm{lb}-\mathrm{cr}$ resistance genes [14]. However, reports about the association of the $q n r B$ with the plasmid replicon types found in this study are limited, as are reports about the qnrS association with HII, Y, and/or FIB plasmid types detected in bovine isolates. The lack of conjugative transfer of the CTX-M-15 determinant (and PMQR associated genes) may indicate that in the other $E$. coli isolates, the resistance determinants were encoded on non-conjugative plasmids.

Class 1 integrons coding for resistance to other antibiotic families were also associated with CTX-M15 producers, though their genetic location was not investigated. However, this finding shows the higher ability of the strains to capture additional resistance genes.

E. coli is commonly associated with urinary tract infections, and the majority of CTX-M-15 strains were found in urine, followed by high vaginal swab samples. Samples were mainly collected at the UCH. This may be due to the fact that most patients in this tertiary care hospital are referred from other hospitals, where they have been started on antibiotherapy. Also, in developing countries like Nigeria, resources are limited and antibiotics are indiscriminately used both in humans and animals, which could result in dissemination of ESBL producers.

In contrast with other Nigerian reports $[6,19,20]$, bovine E. coli isolates did not show considerable resistance, which may be attributed to less bovine antibiotic dosing in this geographic location. The predominant resistance rate was seen for tetracycline (44\%), followed by trimethoprim (25\%). Resistance to amoxicillin was detected in $23 \%$ of the strains, correlating with data obtained from reports on bacteria isolated from meat tables in the geographical location where the study was conducted [20].

The use of cephalosporins and fluoroquinolones for prophylaxis and treatment of bovine animals is rare in Nigeria, which supports the high rates of susceptibility of E. coli bovine isolates. However, these resistance determinants may be selected by other drugs frequently used in food animals. Chah et al. [19] reported the wide use of ampicillin in poultry production in Nigeria, which may provide a selective pressure favoring the emergence of $E$. coli strains that carry plasmids with TEM-1/2 and ESBL determinants. These other food animals may serve as reservoirs of ESBL-producing E. coli strains that could be transferred to humans and other animals. However, in this study, we could not find an association between $E$. coli from human and bovine origins.

The study reports the prevalence of CTX-M-15 in human clinical Nigerian E. coli strains carrying genetic mobile elements such as conjugative plasmids and class 1 integrons that can amplify the spread of resistance in the country, reinforcing the crucial need for antimicrobial surveillance in a country where overthe-counter antibiotic sales and indiscriminate use of antibiotic are common.

\section{Acknowledgements}

C. Inwezerua was supported by a grant of the Scholarship Program for Young African Researchers of Coimbra Group, University of Coimbra, Portugal. N. Mendonça and S. Domingues were supported by the grants SFRH/BPD/45815/2008 and SFRH/BD/49061/2008, respectively, from Fundação para a Ciência e a Tecnologia, Lisbon, Portugal. This work was supported financially by the ESCMID 2010 Research Grant from the European Society of Clinical Microbiology and Infectious Diseases, the PTDC/AGR-ALI/113953/2009 project from Fundação para a Ciência e a Tecnologia and by the Center for Pharmaceutical Studies, University of Coimbra.

The authors would like to thank Dr. Alessandra Carattoli for the kindly gift of the positive controls included in the PCRs for plasmid incompatibility groups.

\section{References}

1. Pitout JD, Laupland KB (2008) Extended-spectrum $\beta$ lactamase-producing Enterobacteriaceae: an emerging public-health concern. Lancet Infect Dis 8: 159-166.

2. Perez F, Endimiani A, Hujer KM, Bonomo RA (2007) The continuing challenge of extended-spectrum $\beta$-lactamases. Curr Opin Pharmacol 7: 459-469.

3. Robicsek A, Jacoby GA, Hooper DC (2006) The worldwide emergence of plasmid-mediated quinolone resistance. Lancet Infect Dis 6: 629-640. 
4. Blomberg B, Jureen R, Manji KP (2005) High rate of fatal cases of pediatric septicemia caused by gram-negative bacteria with extended spectrum $\beta$-lactamases in Dar es Salaam, Tanzania. J Clin Microbiol 43: 745-749.

5. Gangoue-Pieboji J, Bedenic B, Koulla-Shiro S (2005) Extended-spectrum $\quad \beta$-lactamase producing Enterobacteriaceae in Yaounde, Cameroon. J Clin Microbiol 43: 3273-3277.

6. Fortini D, Fashae K, Garcia-Fernandez A, Villa L, Carattoli A (2011) Plasmid-mediated quinolone resistance and $\beta$ lactamases in Escherichia coli from healthy animals from Nigeria. J Antimicrob Chemother 66: 1269-1272.

7. Clinical and Laboratory Standards Institute (2010) Performance Standards for Antimicrobial Susceptibility Testing; Twentieth Informational Supplement. M100-S20. CLSI: Wayne, PA.

8. Jarlier V, Nicolas MH, Fournier G, Philippon A (1988) Extended broad-spectrum $\beta$-lactamases conferring transferable resistance to newer $\beta$-lactam agents in Enterobacteriaceae: hospital prevalence and susceptibility patterns. Rev Infect Dis 10: 867-878.

9. Mendonça N, Leitão J, Manageiro V, Ferreira E, the Antimicrobial Resistance Surveillance Program in Portugal, Caniça M (2007) Spread of extended-spectrum $\beta$-lactamase CTX-M producing Escherichia coli clinical isolates in community and nosocomial environments in Portugal. Antimicrob Agents Chemother 51: 1946-1955.

10. Cattoir V, Poirel L, Rotimi V, Claude-James S, Nordmann P (2007) Multiplex PCR for detection of plasmid-mediated quinolone resistance $q n r$ genes in ESBL-producing enterobacterial isolates. J Antimicrob Chemother 60: 394397.

11. Park CH, Robicsek A, Jacoby GA, Sahm D, Hooper DC (2006) Prevalence in the United States of $a a c\left(6^{\prime}\right)-I b-c r$ encoding a ciprofloxacin-modifying enzyme. Antimicrob Agents Chemother 50: 3953-3955.

12. Barlow RS, Pemberton JM, Desmarchelier PM, Gobius KS (2004) Isolation and characterization of integron containing bacteria without antibiotic selection. Antimicrob Agents Chemother 48: 838-842.
13. Levesque C, Piche L, Larose C, Roy PH (1995) PCR mapping of integrons reveals several novel combinations of resistance genes. Antimicrob Agents Chemother 39: 185-191.

14. Carattoli A, Bertini A, Villa L, Falbo V, Hopkins KL, Threlfall EJ (2005) Identification of plasmids by PCR-based replicon typing. J Microbiol Methods 63: 219-228.

15. Mohapatra BR, Broersma K, Mazumder A (2007) Comparison of five rep-PCR genomic fingerprinting methods for differentiation of fecal Escherichia coli from humans, poultry and wild birds. FEMS Microbiol Lett 277: 98-106.

16. Wirth T, Falush D, Lan R, Colles F, Mensa P, Wieler LH, Karch H, Reeves PR, Maiden MCJ, Ochman H, Achtman M (2006) Sex and virulence in Escherichia coli: An evolutionary perspective. Mol Microbiol 60: 1136-1151.

17. Ogbolu DO, Daini OA, Ogunledun A (2011) High Levels of multidrug resistance in clinical isolates of gram-negative pathogens from Nigeria. Int J Antimicrob Agents 37: 62-66.

18. Aibinu I, Odugbemi T, Koenig W, Ghebremedhin B (2012) Sequence type ST 131 and ST 10 complex (ST 617) predominant among CTX-M-15 producing Escherichia coli isolates from Nigeria. Clin Microbiol Infect 18: E49-51.

19. Chah KF, Oboegbulem SI (2007) Extended-spectrum $\beta$ lactamase production among ampicillin-resistant Escherichia coli strains from chicken in Enugu State, Nigeria. Braz J Microbiol 38: 681-686.

20. Ajayi AO, Oluyege AO, Olowe OA, Famurewa O (2011) Antibiotic resistance among commensal Escherichia coli isolated from faeces of cattle in Ado-Ekiti, Nigeria. J Anim Vet Adv 10: 174-179.

\section{Corresponding author}

Gabriela Jorge da Silva, PhD

Center of Pharmaceutical Sciences, Faculty of Pharmacy

Health Sciences Campus, University of Coimbra

3000-548 Coimbra, Portugal

Phone: +351239488460

Email: gjsilva@ci.uc.pt; silva.gj@gmail.com

Conflict of interests: No conflict of interests is declared. 